\title{
MULTILATERALISM, DEMOCRAȚIE, CONCERT DE PUTERE: LINIILE ROȘII ALE RUSIEI
}

\author{
MULTILATERALISM, DEMOCRACY, CONCERT OF POWERS: \\ RUSSIA'S RED LINES
}

\author{
Conf.univ.dr. Iulian CHIFU*
}

\begin{abstract}
Dezbaterea privind reașezarea lumii este la vârf. Diverse state propun abordări nuanțate și soluții care să permită o reflectare mai pronunțată în guvernanța globală a propriilor interese. Conceptele sunt relativizate, și revizionismul este ascuns cu atenție în spatele respectului față de dreptul internațional, reguli și angajamente; ca și în cazul democrației, îmbrățișată formal de către toți actorii internaționali și subiect a numeroase interpretări din partea foarte multor actori. Multilateralismul nu pare nici el să însemne același lucru pentru diferiți actori, și noile inițiative sunt subminate de pe pozițiile unei frici crescânde de a nu fi lăsat deoparte în marile dezbateri privind viitorul lumii. Dar fapt este că un rol major îl va juca şi în viitor continuitatea, un sistem sofisticat care va păstra toate alternativele, va fi funcțional, iar privilegierea pe rând a uneia sau alteia dintre formele de gestionare va depinde doar de alegerea globală, de atracția și de influența unui proiect sau a altuia, a unui model actual sau viitor. Acest model de coexistență a cercurilor multiple va fi presat de noile inițiative și de influența lor, de numărul de participanți și de amprenta geopolitică a modelului la nivel global a celor care optează și privilegiază un proiect sau altul.
\end{abstract}

The debate for resettling the world is at its peak. Different states are proposing nuanced approaches and solutions that would enable a better grip on the global governance of their own interests. Concepts are relativized and revisionism is carefully hidden beneath respect for the international rules and commitments. As is the case with democracy, embraced by all international players and subject to numerous interpretations by several actors. Multilateralism does not seem to mean the same to different stakeholders and new initiatives are challenged from the positions of a raising fear to be let aside in the big debates about the future world. But the fact is that continuity will play a role, a sophisticated system holding all alternatives will be in place and privileging one or another form is just a matter of global choice, appeal and influence of a project or another, a model or the next. This multiple circles coexistence model could be challenge by the new initiatives and their influence, the number of participants and their geopolitical footprint at the global level.

Cuvinte-cheie: Concert de Putere; multilateralism; politica de putere; Politica de Mare Putere; sfere de influență; suveranitate limitată.

Keywords: Concert of Powers; multilateralism; power politics; Big Power Politics; spheres of influence; limited sovereignty.

\section{Alternativele teoretice ale conducerii lumii}

Modul în care sunt organizate relațiile internaționale și securitatea globală reprezintă un model alternativ, de excludere a uneia prin cealaltă, existent dintotdeauna. De fapt, toată dezbaterea privind alternativele este una care depinde de câteva linii de gândire care au creat diferite doctrine. La nivel teoretic, toate modelele sunt interesante, în egală măsură, cu plusuri și minusuri. Dar în viața reală, fiecare model este dependent de situația reală a lumii la un anumit moment, cuantificând realitățile

\footnotetext{
*Universitatea Națională de Apărare „Carol I” e-mail:keafuyul@gmail.com
}

și relațiile de putere dintre marii jucători, liniile de gândire și modelele considerate mai apropiate de realitatea pe care o reprezintă și urmând tendințele și dezvoltările momentului.

Concret, la nivel teoretic, modelele de gestionare a relațiilor internaționale se împart în câteva categorii:

- Lumea G0 - fiecare pentru el, Lumea Nimănui - No one's World ${ }^{1}$, un nivel crescut de anarhie cu anumite reguli locale sau regionale, introduse în zone în care există un actor important cu interese mari, voința de a gestiona și de a urma reguli, dar și suficiente resurse pentru a face ca aceste reguli pe care le stabilește să fie respectate. Firește că ele sunt subiecte ale unor provocări și contestări în consecință. 
- O lume hegemonică - o putere dominantă, cu suficientă forță, resurse și hotărâre pentru a desena și a gestiona sistemul. Un sistem deschis contestărilor din partea puterilor în expansiune sau a alianțelor dintre diferiții actori, iar sistemul poate funcționa atât timp cât există o cooperare cu alte puteri mari din sistem sau o capacitate suficientă pentru a obliga aplicarea regulilor impuse sistemului.

- Politica de Mare Putere - Concertul de Putere - Bipolarism - sunt soluții aparținând aceleiași familii, cu nuanțe specifice.

Astfel, Politica de Mare Putere se traduce printr-o înclinație a Marilor Puteri de a-și recunoaște una celeilalte statutul, de a și-1 respecta şi de a ajunge la un acord într-un Mare Târg - Big Bargain - pe seama celorlalţi actori internaționali, în loc de a se lupta într-un război, ori de câte ori acest lucru este posibil.

Concertul de Putere se referă la Concertul European de Putere din 2015 și înseamnă că un număr de mari puteri, recunoscându-și statutul și interesele, negociază o abordare comună a lumii, reguli comune de cooperare, impuse, ulterior, tuturor actorilor internaționali.

Bipolarismul este situația în care lumea este împărțită în două, pe baza diferențelor ideologice și a două modele opuse, iar aceste falii creează două blocuri opuse, care se confruntă unul cu celălalt, fără să implice direct cele două Mari Puteri, care sunt centrele de coagulare a matricei celor două blocuri. Regulile și acordurile vin în urma negocierilor celor doi actori principali, singurele superputeri sau mari puteri din sistem.

Multilateralismul - înseamnă implicarea, în orice decizie internațională, a tuturor statelor care sunt actori internaționali, pe picior de egalitate, în cadrul dezbaterii - pe baza egalității suverane - prin exprimarea individuală a preferințelor, pe baza votului majoritar, în urma unei dezbateri universale.

Pentru fiecare model teoretic, există condiții stricte pentru a deveni dominante și prezente pe arena internaţională:

G0 sau lumea anarhică este forma naturală de evoluție a lumii, în care fiecare actor este înclinat să-și urmeze propriile reguli și interese, acomodându-și relațiile cu alți actori și preferințele acestora, fără a exista un model dominant sau reguli care să fie impuse de cineva din sistem. Este o reflectare directă a libertății din sistem. Este și ceea ce regăsim, de obicei, în arena internațională (înaintea apariției înțelegerilor globale).

Lumea hegemonică are nevoie de o putere majoră, cu suficiente resurse și voinţă ca să gestioneze lumea, în cea mai mare parte, pentru a impune viziunea și modelele sale și pentru a întări aceste reguli pe care le-a creat. Există câteva referințe pentru perioada de după căderea Zidului Berlinului, cu SUA devenit hegemon în sistem. Totuşi, modelul este mai apropiat situaţiei Lumii Imperiului Roman sau Lumii Grecești, în timpurile marilor imperii, care acopereau lumea cunoscută cu regulile lor şi cu puterea militară, cu capacitatea de proiecție a puterii și legilor și cu capacitatea de a le aplica.

Concertul de putere pare cea mai naturală formă de aranjament atunci când există o conștiință colectivă pentru a oferi un aranjament și pentru a evita conflictele de mare intensitate, dar ține, de asemenea, de nivelul puterii geopolitice a principalilor actori, ca și de voinţa și determinarea de a se implica mai mult decât în a-și apăra interesele individuale imediate. Am avut câteva încercări, dar modelul nu a putut evita războiul (decât pe perioade relativ scurte de timp, mai puţin de o generație). Şi, acest lucru a fost posibil atât timp cât diferența de potenţial dintre acești mari jucători, mari actori, big actors, și cei mici a fost suficientă pentru a impune abordarea dominantă, agreată fără prea multă durere și prea multe costuri.

Concertul European de Putere de la Viena, 1815, întâlnirea, de la Yalta, dintre SUA, Uniunea Sovietică și Marea Britanie, în calitate de membri permanenți ai Consiliului de Securitate, cu drept de veto, pot fi modele pentru Concertul de Putere. Pactul secret Ribbentrop-Molotov din 1939 și perioada Războiului Rece pot fi momente de bipolarism și sfere de influență agreate reciproc, cu Politica de Mare Putere și Mari Târguri, pe seama celorlalti actori din sistem.

În fine, dezbaterile Adunării Generale a ONU și regulile votării rezoluţiilor neobligatorii sunt o reflectare a multilateralismului.

\section{Liniile roșii ale Rusiei. O teorie asupra întăririi regulilor la nivel global şi internațional}

La 21 aprilie, președintele Rusiei, Vladimir Putin, a prezentat un discurs despre starea națiunii în fața Adunării Federale ${ }^{2}$, care a devenit faimos, 
din cauza referinței la „liniile roșii” care nu trebuie trecute. Criticând faptul că, ,colegii occidentali resping cu încăpățânare propunerile numeroase ale Rusiei”3, președintele Putin notează că „mișcările neprietenești împotriva Rusiei au continuat neabătut. Unele țări au făcut un obicei, se pare, din a se lua de Rusia fără motiv, cel mai adesea, fără niciun motiv. A devenit un fel de sport nou despre cine strigă cel mai tare"4.

În acest cadru și context, președintele Putin a făcut celebra sa declarație:

„Noi chiar dorim să menținem relații bune cu toți cei angajaţi în comunicarea internațională, inclusiv, apropo, cu cei cu care nu am fost în cele mai bune relații în ultima vreme, ca să o spun mai blând. Noi chiar nu dorim să ardem podurile. Dar dacă cineva ia din greșeală bunele noastre intenții drept indiferență sau slăbiciune și intenționează să ardă sau chiar să arunce în aer aceste poduri, trebuie să știe că Rusia va răspunde asimetric, rapid și puternic.

Cei care sunt în spatele provocărilor care ameninţă interesele noastre fundamentale de securitate vor regreta ceea ce au făcut într-un mod în care nu au regretat nimic de multă vreme.

În același timp, tocmai am fost foarte clar, avem suficientă răbdare, responsabilitate, profesionalism, încredere de sine și certitudine legat de cauza noastră, ca și bun simt, când luăm decizii de orice fel. Dar sper ca nimeni să nu se gândească să treacă «linia roșie» în ceea ce privește Rusia. Vom stabili noi înşine, în fiecare caz specific în parte, unde va fi aceasta trasată" ${ }^{\prime \prime}$.

Astfel, liniile roșii invocate sunt legate, în declarația lui Vladimir Putin, de arderea sau aruncarea în aer a relațiilor-lipsă de comunicare sau izolarea Rusiei pe arena internațională -, provocări care amenință interese de securitate esențiale pentru Rusia. Rusia va stabili unilateral aceste linii roșii și le va întări, și aceste linii roșii vor fi stabilite de la caz la caz, aceasta implicând o amenințare clară, venită din partea Rusiei, pentru un răspuns asimetric, rapid şi puternic. Această abordare poate fi lesne prezentată ca o amenințare directă de folosire a forței în afacerile internaționale.

Şi, putem vedea acest lucru în toată media centrală din Occident. BBC a interpretat faptul că Putin avertizează Occidentul ${ }^{6}$, și purtătorul de cuvânt al președintelui Putin, Dmitri Peskov, a descris, ulterior, „liniile roșii” drept ,interesele noastre de securitate externe, interesele de securitate interne în prevenirea oricărui amestec străin, fie în alegerile noastre, fie în alte procese politice interne"7. Pe de altă parte, aducerea în discuţie a ,răspunsului asimetric" al Rusiei la acțiunile occidentale este o abordare mai veche, dar este pentru prima oară când avem referirea la existența unor linii roșiii $\mathrm{Nu}$ există nicio referire la substanţa liniilor roșii invocate, mai mult, declarația permite Rusiei să transforme aceste linii roșii într-o țintă mișcătoare, adică să adapteze aceste linii potrivit voinței sale unilaterale. În același timp, fără o definire clară a percepției Rusiei asupra liniilor roșii, cum ar putea ca aceste linii să fie respectate de cineva vreodată?

Originile ideii de Linii Roșii (la francezi, expresia este de linii galbene, având același înțeles - les lignes jaunes) datează de la 31 iulie 1928, când a fost semnat Acordul Liniilor Roșii ${ }^{9}$, în urma înţelegerii dintre partenerii Companiei Iraq Petroleum, potrivit cărora nu trebuia să își atingă independent interesele în domeniul petrolier în cadrul Imperiului Otoman, care cădea la acea vreme; a nu trece o anumită linie arbitrar trasă pentru a împărți spațiul. În termeni concreți, înseamnă stabilirea unor condiții care nu trebuie să fie încălcate, sub ameninţarea utilizării forței și a unor costuri enorme, în cazul încălcării acestor condiții. În dreptul internațional, liniile roșii sunt interzise per se, pentru că asta înseamnă introducerea unor condiții unilaterale și ameninţarea cu folosirea forței împotriva unui actor internațional.

Pe de altă parte, există și un alt înțeles la care a recurs, de exemplu, președintele Barack Obama, în contextul utilizării de Siria a armelor chimice împotriva propriei populații ${ }^{10}$. Este legat de respectarea dreptului internațional, a regulilor internaţionale stabilite și a angajamentelor unei țări și trasează o limită în timp sau un ultimatum de a se retrage dintr-o asemenea poziție și de a reveni în cadrul limitelor unei poziții agreate, unui comportament sau unei reguli, în caz contrar, va suferi consecințele. Cele două interpretări sunt contrare, pentru că ultima se referă la a obliga pe toată lumea să respecte dreptul internațional și angajamentele asumate, cu bună credință, bona fides, sau să sufere consecințele - care nu implică în mod necesar utilizarea forței, în primul caz, fiind vorba despre pretenții unilaterale și despre amenințarea cu recurgerea la forță. 
Deci Liniile roșii ale Rusiei sunt legate direct de o abordare unilaterală, ilegală, potrivit Cartei ONU, condamnată de dreptul internațional, care include amenințarea cu utilizarea forței. Linia roșie la care se referă președintele Obama este legată de întărirea dreptului internațional și de aplicarea lui, de angajamentele statelor și de semnătura pe un tratat internațional, fapt care e parte a principiului bona fides, a respectării cu bună credință a angajamentelor internaţionale asumate. De aici înainte, avem ilustrarea clară a antagonismului dintre legea forței, în primul caz, și forța legii, în cel de-al doilea.

\section{Serghei Lavrov și ,adevăratul multilateralism" în cadrul Consiliului de Securitate al ONU}

$\mathrm{O}$ anumită clarificare în legătură cu liniile roșii ale Rusiei, invocate în discursul lui Vladimir Putin referitor la starea națiunii, din 21 aprilie 2021, poate fi găsită în declarația lui Serghei Lavrov, la dezbaterea online, organizată de China, făcută din poziția de președinte în exercițiu al Consiliului de Securitate, la 7 mai 2021. In acel discurs, care trebuia să se concentreze pe dezbaterea privind multilateralismul, Ministrul de Externe al Federației Ruse a subliniat ${ }^{11}$ propria sa interpretare referitor la ceea ce Rusia înțelege prin ,,adevăratul multilateralism":

„Este clar că perspectivele de dezvoltare sustenabilă și predictibilă a comunității internaționale sunt legate direct de abilitatea noastră de a găsi soluții eficace la problemele comune și de dorinţa noastră de a exercita un leadership colectiv, pentru ca adevăratul multilateralism să prevaleze" 12 .

Liniile roșii descrise de Lavrov și Rusia sunt: toate regulile internaționale trebuie stabilite în cadrul ONU, cu Rusia având drept de veto în toate chestiunile, incluzând Noua Ordine Mondială ${ }^{13}$ :

„Rusia, ca majoritatea statelor, este convinsă că o asemenea muncă trebuie dusă doar pe baza normelor dreptului internațional, recunoscute universal (...). Organizația Naţiunilor Unite trebuie să servească drept platformă cheie pentru eforturile coordonate: este coloana vertebrală a ordinii globale moderne, în care toate statele independente sunt reprezentate. Astăzi, legitimitatea sa unică și capabilităţile sale unice sunt necesare cu precădere. Principalele prevederi ale dreptului internațional încastrate în Carta ONU au trecut testul timpului.
Rusia cere tuturor statelor să respecte necondiționat motivațiile și principiile Cartei (...)"14.

Rusia dorește să revină la aranjamente de tip Yalta și la Politica de Mare Putere a Marilor Târguri - Big Bargain - pentru a așeza lumea de mâine, amintind de propunerea lui Vladimir Putin referitoare la o reuniune a membrilor permanenți ai Consiliului de Securitate al ONU, pentru acest târg, sau cel puțin o întâlnire SUA-Rusia, pentru a aranja regulile jocului în viitor. Dar, în același timp, limitele date de respectarea statu-quoului sunt date de „un echilibru stabil de interese” și de „noile realități" 15 care pot da cale liberă revizionismului, sub o altă etichetă:

„Este necesar să prezervăm baza legală internațională recunoscută, pentru a construi un echilibru de interese stabil care se pliază pe noile realități.(...) Ce poate fi mai natural decât discutarea țintelorpentruîntărirea multilateralismului la ONU? (...) Acest fapt dovedește atitudinea adevărată a Occidentului față de multilateralism și ONU, pe care nu le privesc drept un format universal pentru dezvoltarea solutiiilor acceptabile tuturor" ${ }^{\prime 16}$.

Rusia respinge, de fapt, conceptul de lume bazată pe reguli și preferă să se refere alternativ la reguli agreate universal/de toată lumea, înțelegând doar pe cele stabilite în cadrul Consiliului de Securitate al ONU:

„Conceptul de lume bazată pe reguli este avansat ca un substitut al dreptului internațional. Trebuie să notăm faptul că dreptul internațional are deja un corp de reguli, dar reguli acceptate pe platforma universală și reflectând consensul sau un acord larg. Obiectivul Occidentului este să se opună eforturilor colective ale tuturor membrilor comunităţii mondiale cu alte reguli dezvoltate în formate închise, neinclusive și apoi impuse tuturor celorlalți. $\mathrm{Nu}$ vedem decât daune în asemenea acțiuni care ocolesc ONU și încearcă să uzurpe singurul proces de decizie care poate reclama relevanță globală" ${ }^{\prime 17}$.

Egalitatea suverană a statelor - un principiu extras direct din Carta ONU - este respins de facto atunci când, pentru Lavrov, Putin și Rusia, numai Marile Puteri se califică pentru a discuta viitorul lumii ${ }^{18}$. Cu Rusia în prim-plan, la masă:

„Membrii permanenţi ai Consiliului de Securitate al ONU sunt chemați să joace un rol cheie în provocarea unui dialog deschis și direct în legătură cu cele mai presante probleme ale 
vremurilor noastre. Potrivit Cartei ONU, ei au o responsabilitate specială pentru a menține pacea și securitatea internațională. Președintele Rusiei, Vladimir Putin, a propus un summit cu liderii celor cinci state membri permanenţi. Sperăm să transformăm această idee în realitate imediat ce situația epidemiologică a lumii se va stabiliza"19.

Desigur, orice altă reuniune a statelor suverane și toate acordurile la care s-a ajuns în afara cadrului ONU și a dreptului de veto al statelor membre permanente ale Consiliului de Securitate sunt respinse de Rusia, inclusiv Summitul Democrațiilor și Alianța pentru Multilateralism, pentru că Rusia nu este prezentă și nu are același drept de veto în acest cadru. Această poziție încalcă direct dreptul statelor de a încheia acorduri internaționale și de a negocia reguli și angajamente convenite mutual, iar acest fapt este permis de dreptul internațional. Cerința de a pune toate instituțiile internaționale, normele și acordurile sub ONU și sub dreptul de veto din Consiliul de Securitate este un exces de interpretare, o pretenție care nu a fost agreată niciodată de comunitatea internațională.

„Ideea bine cunoscută de a organiza un Summit al Democrațiilor, propus de Administrația Statelor Unite este în același sens. Stabilirea unui nou club, bazat pe interese, cu o bază ideologică clară are potențialul de a inflama și mai mult tensiunile internaţionale și de a adânci liniile de diviziune, într-o lume care are nevoie de o agendă unificatoare mai mult decât oricând (...). O altă inițiativă, cu scopul de a realiza leadershipul global, ocolind ONU este ideea franco-germană de a crea o Alianță pentru Multilateralism. (...) Iniţiative ambițioase noi de a crea parteneriate înguste apar tot timpul în cadrul Alianței pentru Multilateralism, pe teme care sunt deja discutate în cadrul ONU sau al agențiilor sale specializate, de exemplu pe cyber security (între 65 de state membre), respectul pentru dreptul internațional umanitar (43 de state membre), parteneriatul pentru informație și democrație (peste 30 de țări) etc." ${ }^{20}$.

\section{Dezbaterea despre multilateralism și nevoia evidentă de reformare a $\mathrm{ONU}$}

Miza reală în dezbatere este idea unui sistem multilateral, cu respectarea egalităţii suverane a statelor, și e legată de regulile de decizie din cadrul Consiliului de Securitate al ONU. Rămășițele acordurilor din cel de-al Doilea Război Mondial sunt încă în vigoare și orice încercare de a le revizui și de a reforma Carta cu privire la acest punct a fost respinsă cu precădere de către membrii permanenți ai Consiliului de Securitate, în ciuda celor mai bune argumente posibile.

Mai întâi, a fost cea despre tabăra perdantă din cel de-al Doilea Război Mondial, care nu a intrat în Consiliul de Securitate, fiind vorba, în primul rând, despre Germania și Japonia. Apoi a fost ideea unei prezențe geografic echilibrate, care ar fi presupus ca India, Brazilia și, poate, Africa de Sud să fie membri permanenți. Regula majorității calificate a grupului de reprezentanți, chiar împărțiți între membri permanenți și nepermanenți, este una potrivită pentru eficiența deciziilor. Dar dreptul de veto al unor anumite state este un atavism important care ar trebui înlocuit. A fost însă respins întotdeauna, chiar și regula abținerii de la a utiliza veto în chestiunile care țin de statul în cauză.

Nevoia de a revizui Carta ONU, ca și regulile Consiliului de Securitate, în primul rând, dreptul de veto al membrilor permanenți, a fost identificată de aproape toți participanții la dezbaterea pe marginea multilateralismului. Chiar și Wang Yi, reprezentantul chinez, și Volkan Bozkir, diplomatul turc care deține poziția de Președinte al Adunării Generale, s-au referit la acest lucru: „În multe ocazii, Consiliul este divizat și nu e capabil să se ridice la nivelul provocărilor. În majoritatea acestor cazuri, motivul eșecului îl reprezintă diferențele dintre membri, cu precădere dintre membrii permanenți”, a spus Volkan Bozkir. Domnul Bozkir a subliniat nevoia de reformă și de apariție a unui consiliu mai reprezentativ, mai responsabil și transparent, afirmând: „O spun în calitate de Președinte al celui mai democratic organism al acestui sistem" 21 , cu referire indirectă la mai puțin democraticul Consiliu de Securitate și la drepturile sale de veto care alterează votul direct.

Wang Yi, consilier de stat și ministru al Afacerilor Externe al Chinei, a discutat direct despre reforma Consiliului de Securitate, pledând pentru o reprezentare mai bună a țărilor în curs de dezvoltare: „ONU are nevoie să menţină pasul cu timpurile și ar trebui să îmbunătățească eficiența, capabilitățile de răspuns de urgență și transparența în activitatea sa prin reformă. Este motivul pentru 
care trebuie să crească reprezentarea și vocea statelor în curs de dezvoltare și să așeze un sistem de guvernanță globală mai just și mai echitabil”22.

Desigur, SUA a avut partea sa în dezbaterea despre multilateralism, care a revenit la realitate, amintind principiile de bază ale Cartei și înțelesul original al semnatarilor. Secretarul de stat Anthony Blinken 1-a citat pe președintele Harry Truman, atacând relativizarea și interpretarea ministrului Lavrov. Menținerea păcii și securității este primul obiectiv al ONU, dar drepturile omului sunt prezente în Articolul 1:

„Cele mai puternice state sunt și ele legate de aceste principii. Au fost de acord cu o formă de autorestrângere - așa cum a spus președintele Truman -, să-și înfrângă dorința de a face tot timpul ceea ce le place - pentru că au recunoscut că acest lucru va servi, la final, nu numai intereselor umanității, ci chiar pe ale lor. SUA a făcut astfel, chiar dacă a fost de departe cea mai puternică națiune a lumii, la acea vreme. A fost interesul său luminat. Noi credem că succesul altor națiuni este critic și pentru noi. Și nu am dorit ca state mai puțin puternice să se simtă amenințate și obligate să se alieze împotriva noastră’’23.

Secretarul de stat Blinken a subliniat, de asemenea, că regulile ar trebui respectate de către membrii permanenţi ai Consiliului de Securitate, în primul rând, și faptul că acest statut cere mai mult de la acești membri și că nu oferă impunitate, dreptul de a ignora regulile sau luarea deciziilor pe seama statelor mai mici. El a mai afirmat și faptul că respectiva Cartă nu se referă, în primul rând, la state, ci este pentru oameni, pentru drepturile și libertățile lor, în egală măsură:

„Această realizare deosebită, cu toate imperfecțiunile sale, a fost o realizare fără precedent. Şi a durat pentru că majoritatea covârșitoare a cetățenilor și națiunilor continua să o vadă ca reprezentându-le interesele, valorile, speranțele (...). În același timp, vom continua să respingem cu putere atunci când vedem statele subminând ordinea internaţională, pretinzând că regulile cu care au fost de acord nu există, sau pur și simplu, încălcându-le cu bună știință. Pentru ca sistemul să livreze, toate statele trebuie să respecte regulile sale și să le aplice pentru succesul său" ${ }^{24}$.

Dar partea cea mai importantă a declaraţiei este legată de o replică la ideea de „,multilateralism adevărat" și de sistem propus de Rusia, revelând, chiar și fără a numi, cele mai importante probleme și provocări ale ordinii internaţionale și ale lumii bazate pe reguli, venind din partea lui Putin și a regimurilor autocratice. El a contestat referirea la neamestecul în treburile interne, susținând că „drepturile omului nu sunt valori subiective care variază de la o societate la alta. Declarația Universală a Drepturilor Omului începe cu cuvântul «universal» tocmai pentru că statele noastre au căzut de acord că există anumite drepturi pe care fiecare persoană, oriunde, le deține. Invocarea jurisdicției interne nu dă nici unui stat un cec în alb pentru a trata ca sclavi, a tortura, a face să dispară, a epura etnic propriul popor sau a încălca drepturile omului în orice alt mod"25.

Anthony Blinken s-a referit, de asemenea, și la un alt principiu al Cartei, principiul egalității suverane a statelor membre, acuzând încă o dată comportamentul Rusiei în arena internațională:

„Un stat dovedește că nu dorește să respecte acest principiu atunci când îsisi permite să redeseneze frontierele altuia; sau când caută să rezolve dispute teritoriale, utilizând sau amenințând cu utilizarea forței; sau atunci când un stat pretinde că are dreptul la o sferă de influenţă pentru a dicta sau impune coerciţia asupra alegerilor și deciziilor altui stat. Și un stat încalcă acest principiu atunci când vizează un altul cu dezinformare și corupție militarizată, subminează alegerile libere și corecte și instituţiile democratice ale altui stat sau se răzbună pe jurnaliști şi dizidenți în afara granițelor sale.

Aceste acțiuni ostile pot, de asemenea, să amenințe pacea și securitatea internațională pe care Carta Națiunilor Unite ne obligă să le apărăm.

Când statele membre ale ONU - cu precădere, membrii permanenți ai Consiliului de Securitate - încalcă aceste reguli și blochează încercările de a-i trage la răspundere pe cei care încalcă dreptul internaţional, atunci transmit mesajul că și alții pot să încalce regulile cu impunitate"26.

\section{Ierarhia instituțiilor internaționale versus libertatea de asociere}

Aceste evoluții sunt cruciale în găsirea drumului spre reașezarea noii ordini mondiale și pentru modul în care se va poziționa fiecare dintre țările implicate în dezbatere. Am văzut deja ideea îmbrăţișată de Statele Unite, potrivit căreia statele democratice sunt în rivalitate directă cu autocrațiile, Statele Unite fiind interesate de un multilateralism real ${ }^{27}$. 
Acest multilateralism implică strângerea laolaltă și conjugarea întregii greutăți a tuturor democrațiilor, fie mari, medii sau mici, pentru a obține convergența ideilor și a pozițiilor, greutatea strategică pentru a obține o majoritate globală dominantă, pentru a contura și a propune regulile generale ${ }^{28}$ și pentru a apăra aplicarea principiilor și angajamentelor existente, nu numai prevederile Cartei ONU.

De fapt, ideea unei ierarhii a instituțiilor în sistemul internațional și al subordonării tuturor organizațiilor internaționale față de ONU și a dreptului său de veto din Consiliul de Securitate este expresia lipsei de democrație, multilateralism și de suveranitate egală a statelor. Din contră, sistemul internaţional, inclusiv cel stabilit prin Naţiunile Unite, este bazat pe democrație, drepturile și libertățile omului și libertatea țărilor de a se asocia liber, pe baza regulilor democratice, traduse la nivel internaţional. Supremația legii, statul de drept, egalitatea suverană a statelor sunt parte din acquis-ul general și orice relativizare a acestor reguli, orice respingere sau limitare a libertăților statelor ori a oamenilor constituie o încălcare a acestei înţelegeri comune a dreptului internațional.

Anarhismul fundamental al sistemului internaţional înseamnă și libertatea statelor de a se asocia în modul pe care îl consideră a fi cel mai potrivit și mai avantajos pentru interesele lor, dar și într-o formă durabilă, respectând același set de principii și valori - și acesta este miezul oricărei înțelegeri, al oricărui acord. Concertul de Putere a fost supralicitat și îmbrățişat pentru eficiența $\mathrm{sa}^{29}$, pentru că vorbim despre consens între câteva state. Dar tocmai experiența și istoria Consiliului de Securitate ne oferă proba că un consens este greu de găsit, comparabil cu cel între un număr mult mai mare de state. Pe de altă parte, UE și NATO au dovedit că, dacă membrii organizației respectă aceleași reguli și își asumă aceleași valori şi principii, se poate realiza și consensul dintre un număr relativ important de actori.

În acest sens, ne-am uitat cu atenție la noile instituții pentru coeziunea democrațiilor. NATO a dezvoltat deja formate cu partenerii globali, dincolo de legătura transatlantică, state care au lucrat împreună în Afganistan, și democrațiile pot repeta această experiență, pe baza principiilor şi valorilor comune care reprezintă matricea de bază a acestor organizații. Comunitatea Democrațiilor este deja coezivă și va rămâne și se va dezvolta, în timp ce summitul democrațiilor, pregătit de SUA, va duce la o coordonare mai bună a statelor democratice. Apoi Alianța pentru multilateralism, pe care Franța și Germania o pregătesc este un alt format care merită luat în considerare. Noile instituții multilaterale ar putea deveni instrumente care pot oferi monitorizarea regulilor și normelor existente, angajamentele și acordurile în vigoare și să pregătească noile reguli necesare dezvoltării noilor tehnologii, în chestiuni legate de spațiul cibernetic, artificial intelligence, spațiu, Marele Nord și zona Arctică $\breve{a s ̦ i ~}^{30}$ așa mai departe.

O croire realistă a Noii Ordini Mondiale ar trebui să aibă în minte o abordare mult mai sofisticată decât una de supersimplificare sau de fetișizare a opțiunilor teoretice pentru resetarea Ordinii Globale. De fapt, toate opțiunile sunt pe masă și toate instrumentele sunt pregătite, unele abordări noi sunt pe care să fie construite și lansate, şi realitatea va permite mecanismelor alternative să fie prezente și utile, atât timp cât există un sprijin pentru unul sau altul dintre ele, la un anumit moment dat, pe o anumită temă în discuție. De fapt, toate coexistă și sunt suprapuse, dar voința statelor şi oamenii se vor raporta alternativ la fiecare dintre ele, și cea mai relevantă dintre acestea, care adună cel mai important sprijin va deveni referențialul pentru soluția la o anumită problemă.

Asta nu înseamnă că totul e perfect sau că nu vor exista ciocniri și conflicte. Dar aceasta este metoda de a evita războaiele și conflictele militare deschise și de a discuta și gestiona problemele lumii într-o formă mai adecvată decât în timpul celui de-al Doilea Război Mondial, cu Pactul Ribbentrop-Molotov, utilizând violența militară și politica de putere, cu Concertul de Putere de la Yalta, rivalităţile Războiului Rece, Mari Târguri, conflicte prin intermediari și Politicile de Mare Putere.

\section{NOTE:}

1 Charles A. Kupchan, No One's World. The West, The Rising Rest and the Coming Global Turn, Oxford University Press, 2013, p. 258; Ian Bremmer, Every Nation for Itself. Winners and Loosers in a G0 World, Portfolio Penguin, 2012, p. 229.

2 Vladimir Putin, Presidential Address to the Federal Assembly, Manezh Central Exhibition Hall, 2021, http:// en.kremlin.ru/events/president/news/65418, accesat la 14.05.2021.

3 Ibidem. 


\section{Ibidem.}

5 Ibidem.

6 [BBC], "Putin warns of tough Russian action if West crosses «red line»", 21 aprilie 2021, https://www.bbc.com/ news/world-europe-56828813, accesat la 13.05.2021.

7 Ibidem.

8 Nikola Mikovici, What are Russia's red lines?, CGTN, 2021, https://news.cgtn.com/news/2021-04-22/What-areRussia-s-red-lines--ZF1SXkzoWc/index.html, accesat la 13.05.2021.

9 Michael Quentin Morton, ”Once Upon a Red Line: The Iraq Petroleum Company Story”, GeoExpro, 6 aprilie 2013, https://www.geoexpro.com/articles/2013/06/onceupon-a-red-line-the-iraq-petroleum-company-story, accesat la 07.05.2021. A trece linia roşie înseamnă a depăşi punctul de întoarcere, adică drumul înapoi spre înțelegere nu mai e posibil.

10 La 20 august 2012, președintele Barack Obama a folosit expresia „linie roșie" referitor la folosirea armelor chimice în războiul civil din Siria, spunând: „Noi am fost foarte clari cu regimul Assad, ca de altfel și cu alți jucători de teren, că o linie roșie înseamnă pentru noi că vom începe să vedem o grămadă de arme chimice deplasate prin zonă sau chiar utilizate". Când au avut loc atacurile chimice de la Ghouta, Obama a clarificat, ulterior: „Nu am stabilit o linie roșie. Lumea a stabilit-o, când 98\% dintre guvernele populației lumii au declarat că folosirea armelor chimice este dezastruoasă și au adoptat un tratat prin care se interzice folosirea lor, chiar și în țările implicate în război” - declarație dată la Chemical Weapons Convention. A se vedea, Michele Richinick Obama: „Nu am stabilit o linie roșie, lumea a stabilit-o", MSNBC, 4 septembrie 2013, https://www.msnbc. com/morning-joe/obama-i-didnt-set-red-line-the-worldmsna155636; Roff Smith, "Red line", National Geographic News, 7 mai 2013, https://www.nationalgeographic.com/ culture/article/130507-red-line-obama-syria-mccainchemical-weapons; Ben Zimmer, "The Long History of the Phrase «Red Line»", The Wall Street Journal, 19 iulie 2013, https://www.wsj.com/articles/SB1000142412788732399380 4578612210634238812; Dot Wordsworth, "What, exactly, is a «red line»?", The Spectator magazine, 8 iunie 2013, https:// www.spectator.co.uk/article/what-exactly-is-a-red-line-, accesat la 18.04.2021.

11 Serghei Lavrov, Foreign Minister Sergey Lavrov's remarks at the meeting of the UN Security Council,

"Maintenance of international peace and security: Upholding multilateralism and the United Nations-centred international system", videoconferință, Moscova, 7 mai 2021, https://www.mid.ru/en/posledniye_dobavlnenniye/-/ asset_publisher/MCZ7HQuMdqBY/content/id/4721942, accesat la 07.05.2021.

12 Serghei Lavrov, op.cit.

13 Iulian Chifu, „Ucenicii vrăjitori care desenează lumea de mâine cu mâna: supra-simplificare şi paseism”, Adevărul, 19 mai 2021, adev.ro/qtc7w3, accesat la 19.05.2021.

14 Serghei Lavrov, op.cit.

15 Iulian Chifu, „Multilateralismul Rusiei: Concertul de Putere de la Yalta, sfere de influenţă şi veto în afacerile globale", Adevărul, 11 mai 2021, adev.ro/qsxepm, accesat la 13.05.2021.
16 Serghei Lavrov, op.cit.

17 Ibidem.

18 Iulian Chifu, op.cit.

19 Serghei Lavrov, op.cit.

20 Ibidem.

21 [UN], Security Council upholds role of multilateralism in a complex world, 7 mai 2021, https://news.un.org/en/ story/2021/05/1091532, accesat la 13.05.2021.

\section{Ibidem.}

23 *** Secretary Antony J. Blinken Virtual Remarks at the UN Security Council Open Debate on Multilateralism, 7 mai 2021, https:// www.state.gov/secretary-antony-j-blinken-virtual-remarksat-the-un-security-council-open-debate-on-multilateralism/, accesat la 13.05.2021.

24 Ibidem.

25 Iulian Chifu, „Multilateralismul Rusiei: Concertul de Putere de la Yalta, sfere de influenţă şi veto în afacerile globale", Adevărul, 11 mai 2021, adev.ro/qsxepm, accesat la 11.05.2021.

26 *** Secretary Antony J. Blinken Virtual Remarks at the UN Security Council Open Debate on Multilateralism, 7 mai2021, https:// www.state.gov/secretary-antony-j-blinken-virtual-remarksat-the-un-security-council-open-debate-on-multilateralism/, accesat la 13.05.2021.

27 Patrick M. Stewart, The Biden Administration and the Future of Multilateralism, European Council of Foreign Relations, 21 aprilie 2021, https://www.cfr.org/blog/ biden-administration-and-future-multilateralism, accesat la 18.04.2021.

28 Joseph Biden Jr., Interim national security strategic guidance, White House, 3 martie 2021, https://www. whitehouse.gov/wp-content/uploads/2021/03/NSC-1v2.pdf, accesat la 07.05.2021.

29 Richard Haass, Charles Kupchan, "The New Concert of Powers", Foreign Affairs, 23 martie 2021, https://www. foreignaffairs.com/articles/world/2021-03-23/new-concertpowers, accesat la 18.04.2021.

30 Iulian Chifu, „Multilateralismul Rusiei: Concertul de Putere de la Yalta, sfere de influenţă şi veto în afacerile globale", Adevărul, 11 mai 2021, adev.ro/qsxepm, accesat la 11.05.2021.

\section{BIBLIOGRAFIE}

*** Secretary Antony J. Blinken Virtual Remarks at the UN Security Council Open Debate on Multilateralism, 7 mai 2021, https://www.state. gov/secretary-antony-j-blinken-virtual-remarksat-the-un-security-council-open-debate-onmultilateralism/

[BBC], "Putin warns of tough Russian action if West crosses «red line»", 21 aprilie 2021, https:// www.bbc.com/news/world-europe-56828813

[UN], Security Council upholds role of multilateralism in a complex world, 7 mai 2021, https://news.un.org/en/story/2021/05/1091532 
Biden Joseph Jr., Interim national security strategic guidance, White House, 3 martie 2021, https://www.whitehouse.gov/wp-content/ uploads/2021/03/NSC-1v2.pdf

Chifu Iulian, ,Multilateralismul Rusiei: Concertul de Putere de la Yalta, sfere de influenţă şi veto în afacerile globale", Adevărul, 11 mai 2021, adev.ro/qsxepm

Chifu Iulian, Ucenicii vrăjitori care desenează lumea de mâine cu mâna: supra-simplificare şi paseism, Adevărul, 19 mai 2021, adev.ro/qtc7w3

Haass Richard, Kupchan Charles, "The New Concert of Powers", Foreign Affairs, 23 martie 2021, https://www.foreignaffairs.com/articles/world/ 2021-03-23/new-concert-powers

Kupchan Charles A, No One's World. The West, The Rising Rest and the Coming Global Turn, Oxford University Press, 2013; Bremmer, Ian, Every Nation for Itself. Winners and Loosers in a G0 World, Portfolio Penguin, 2012.

Lavrov Serghei, Foreign Minister Sergey Lavrov's remarks at the meeting of the UN Security Council, "Maintenance of international peace and security: Upholding multilateralism and the United Nations-centred international system", videoconferință, Moscova, 7 mai 2021, https:// www.mid.ru/en/posledniye_dobavlnenniye/-/ asset_publisher/MCZ7HQuMdqBY/content/ id/4721942

Mikovici Nikola, What are Russia's red lines?, CGTN, 22 aprilie 2021, https://news.cgtn.com/
news/2021-04-22/What-are-Russia-s-red-lines-ZF1SXkzoWc/index.html

Morton Michael Quentin, Once Upon a Red Line: The Iraq Petroleum Company Story, GeoExpro, 6 aprilie 2013, https://www.geoexpro. com/articles/2013/06/once-upon-a-red-line-theiraq-petroleum-company-story

Putin Vladimir, Presidential Address to the Federal Assembly, Manezh Central Exhibition Hall, 21 aprilie, 2021, http://en.kremlin.ru/events/ president/news/65418

Richinick Michele, Obama: "I didn't set a red line, the world set a red line", MSNBC, 4 septembrie 2013, https://www.msnbc.com/morning-joe/obama -i-didnt-set-red-line-the-world-msna 155636

Smith Roff, "Red line", National

Geographic News, 7 mai 2013, https://www.natio nalgeographic.com/culture/article/130507-red-line -obama-syria-mccain-chemical-weapons

Stewart M. Patrick, The Biden Administration and the Future of Multilateralism, European Council of Foreign Relations, 21 aprilie 2021, https://www.cfr.org/blog/biden-administrationand-future-multilateralism

Wordsworth Dot, "What, exactly, is a «red line»?", The Spectator Magazine, 8 iunie 2013, https://www. spectator.co.uk/article/what-exactly-is-a-red-line-

Zimmer Ben, "The Long History of the Phrase «Red Line»", The Wall Street Journal, 19 iulie 2013, https://www.wsj.com/articles/SB100014241 27887323993804578612210634238812 